\title{
From Social Polarity to Mental Polarity: Tracing the Paradigmatic Shifts in the Conception of "Caste" in Kerala
}

\author{
Jyothi lekshmi G
}

Guest Lecturer in English, NSS College Nilamel, Kerala.

\begin{abstract}
This paper aims to analyze the shift in casteism in Kerala society through selected prominent literary works of the times. While N. Kumaranasan dealt with the social marginalization practiced against "untouchables" in Chandalabhikshuki, O. Chandu Menon in Indulekha tries to represent the internal casteist conflict among the "upper castes". The Renaissance movement led by SreeNarayana Guru, Ayyankali and Mannathu Padmanabhan heralded a new era in Kerala's social scenario by toppling down, to a great extent, the segregation prevalent in the society. Besides Renaissance movement, a further shift occurred in the Malayali casteist mindset with the progressive Communist movements as well. Thakazhi's novels like Randidangazhi and Thottiyude Makan succeeds in addressing the problems of lower castes while emphasizing the role of class struggle within casteism. Furthur, P.Kesava Dev pointed out in his Ayalkar that with the emergence of Communist movement, there occurred a significant amelioration of Ezhava community. The deterioration of theocratic feudalism and matrilineal system, also contributed considerably to build a more inclusive Keralite society. Casteism, during those times, has received much condemnation but paradoxically it had a large number of adherents in practice. Towards the end of twentieth century, "the caste", which was publicly condemned till then, began reasserting itself in the minds of Malayalis. O.V. Vijayan through his work Thalamurakal throws light on the implicit casteism and Malayali's propensity to attain Brahmanism to be on par with the "upper castes". Truly, no one dare to speak out "caste" in today's Kerala but the hard fact that caste is deeply ingrained in the mental fabric of Keralites cannot be left unnoticed. Manushyanu Oru Aamukham, the Sahitya Akademi Award winning novel by Subhash Chandran, fundamentally presumes every educated Keralite who swears against casteism, as being unknowingly bound by it.
\end{abstract}

Keywords: Casteism, Social Marginalization, Indulekha, Chandalabhikshuki, Renaissance Movement, Randidangazhi, Thottiyude Makan, Theocratic Feudalism, Thalamurakal, Manushyanu Oru Aamukham

\section{INTRODUCTION}

Caste which was a social phenomenon once linked to the occupation of people, have now become a household matter for the Kerala society almost in its entirety. Today its prominence, undeniably, ranges from a child's school admission to his/her nuptial priorities. In this paper, I attempt to trace the major changes in caste system in Kerala, from nearly 6th Century to twenty-first century. Formation of caste in Kerala, akin to other states in India, definitely, had its origin in the Brahmanical hegemony that divided the people of Kerala (as we call today), into Brahmin followers and non- followers. Obviously, the "upper caste" title was adorned by the Brahmin followers, leaving the rest as "lower castes" or "untouchables". This paper aims to analyze the shift in casteism in Kerala society through selected prominent literary works of the times. Till twentieth century, untouchability, social marginalization and ostracizing, predominantly on the ground of caste were practiced in Kerala. But when time steps into twenty first century, the conception of caste itself takes a much more terrific turn, metamorphosing itself from a much violent form to a more dangerous "silent" form.

\section{ANAlysis}

"Nair girl, 24 years, Bank officer, seeks alliance from educated Nair boys". There would not be any Malayali who would feel strange on seeing this advertisement. Perhaps, no better advertisement stands as testimonial to the casteism that is inextricably weaved into the fabric of the Keralite mindset. Caste, which was a social phenomenon once linked to the occupation of people, have now become a household matter for the Kerala society almost in its entirety. Today its prominence, undeniably, ranges from a child's school admission to his/her nuptial priorities. 
The caste system finds no mention in the Sangam works which were written during or prior to $2 \mathrm{AD}$. The merging of Aryan Brahmanism with the existing Gothras in Cheranadu led to the origin of caste system in kerala. Theocratic feudalism which prevailed, paved way for the casteism in Kerala. At its inception, caste was purely on occupational basis and not on birth. Untouchability and unapproachability were not practiced and even in the king's court, a lower caste and a Brahmin had equal status, had they proven their scholarship.

During the 9th century, the priestly class organized and consolidated themselves in a better way and their influence on political matters of the day became significant. This furthur established the foundation of caste system in Kerala. Then, the society was divided into those affiliated to Brahmanism, accepting its dominance and those in opposition to the Brahmanical supremacy. The followers of Shaiva- Vaishnava sect accepted Brahmanical Supremacy and those who did not, mainly comprised of Jains and Buddhists. Thus on the whole, Kerala society was divided into Hindus and non- Hindus. The followers of Hinduism were further divided on the basis of Varnas. Consequently, there were Brahmins, Kshatriyas and since the merchants in Kerala were Arabs, Jews and Christians, there were no Vaishyas and the rest who accepted Brahmanic religion were classified as Shudras. Nair community belonged to the Shudra class. A group of Buddhists who opposed Brahmanism was present in Kerala. But as Hinduism gained more prominence, they converted to Hinduism. Varna system within Hinduism did not encompass these converted followers who were segregated as "Avarnas" or "untouchables". Based on their occupation and economic status, they were further divided into several castes. But the scholars and priests among the Buddhists were included in Hinduism, not as "untouchables" but as Brahmins. The political power exerted by the Brahmins was crucial in determining the structure of Kerala society. This led to the development of theocratic feudalism. Jati hierarchy was, in short, the effect of Brahmanical form of social representation that became hegemonic around the sixth- seventh century AD.

The caste differentiation which sprouted in the sixth and seventh century AD cannot be considered on par with the caste discrimination that prevailed in the 19th century. The caste politics which was evident between 1860 and 1910 could be fundamentally distinguished from the caste system that existed during early 6th century AD. Towards the end of the 19th century, the casteism in Kerala deteriorated from its initial stratification and got deeply ingrained in the minds of Keralites, rather than on their social fabric. P.K. Balakrishnan observes that exploitation of any kind was distant from the Kerala society. Moreover the people in Kerala focused more on their self-accomplishments, which subsequently gained them better social standing. With better living standards, social stratification became more evident. The people enjoying better life standards, especially the Namboodiri community in Kerala, started exploiting the lower castes to meet their ends. InIndulekha(1889), the novel written by $\mathrm{O}$. Chandu Menon, the warm but exploitative relationship between Namboodiris and Nairs are exposed. Soori Namboodiri, the man who comes to marry Indulekha is a representative of the entire Namboodiri community in Kerala during that time. Indulekha brings to the limelight the failures of the matrilineal system which prevailed in the Nair community and the absurdity of "sambandham" which tacitly asserted the Brahmanical supremacy. The social stratification in Kerala did not merely end with this caste formation. But there were many sub castes within each castes wherein there was another kind of discrimination practiced. Though Sheenupattar and Soori Namboodiri belonged to the same Brahmin community, Sheenu was marginalized to the status of a mere caretaker. The follies and foibles committed by Soori to marry Indulekha exposed the frailties of the entire Namboodiri community. Besides Soori Namboodiri, there is Karuthedathu Kesavan Namboodiri, the husband of Indulekha's mother, who reminds of the link between Namboodiris and Nairs through "sambandham".

Joint family system or specifically matrilineal system prevalent in the Nair community curtailed the freedom and individuality of the family members to a great extent. In Induekha, Madhavan tries to overcome this yoke and assert his individuality and self -reliance. Though his endeavours did not meet complete success, it paved way for a new wave of thought in the Kerala Society.

Moreover with the introduction of English education, a huge drift occurred in the conception of casteism in Kerala. The educated people from the upper castes consolidated themselves, opposing the matriarchal structure of society thereby focusing more on individual selves. This shift in focus indeed 
laid the foundation stone of Renaissance in Kerala. Truly, the skirmishes present among the upper castes which was nurtured by the British education, created an educated "civilized" class and "common" people. Thus the whole question of theocratic feudalism was on the verge of subversion.

From Panchumenon's decision to sue a petition to retrieve land from Soori Namboodiri, the growing intolerance towards Brahmanical feudalism is explicit. In Indulekha, the most deteriorated stage of theocratic feudalism is portrayed. Though a democratization of Keralite society through English education could not be attained, a consequential community based liberalism which offered a wide perspective of the world emerged.In other words Indulekha marks the threshold between the decline of feudalism and the emergence of Industrial capitalism.

The decline of feudalism which had its beginning in Indulekha reached its climax in the nineteenth century with the Kerala Renaissance movement.Undeniably the 19th century Kerala society was steeped in religious superstition and social obscurantism. The upper caste Hindus, especially the Brahmins exercised an overwhelming and decisive influence over the lower castes. The Brahmins also had the exclusive right to preach religious doctrines, to officiate as priests and to function as teachers. Other castes were debarred from all forms of higher education.

The caste system, then prevailing in Kerala was much more oppressive than that prevailing in other parts of India. The practice of untouchability, unapproachability and unseeability militated against human dignity. Government offices, courts and schools were not open to the lower castes. They were prohibited from entering public roads, temples, palaces etc. thus the rules and regulations of caste hampered social mobility, fostered social division and sapped individual initiative. By the end of 19th century, organizations based on caste identities had become a reality. As an important effort to put an end to caste, these organisations strove hard to bring about homogeneity within the caste, which was further divided. The national leaders who emerged from Kerala found that caste system militated against patriotic feeling and negated the growth of democratic ideas. The people belonging to lower castes believed that the caste system was not conducive to their economic development. This necessitated a change in the existing caste system which kept the people segregated socially and politically.

N. Kumaranasan, the poet and follower of SreeNarayana Guru, makes his writings the voxpopuli against untouchability. His poems Duravastha and Chandalabhikshuki storms against the prevailing caste discrimination. His characters represent all sorts of atrocities committed by the upper castes, mainly through the garb of Chathan in Duravastha and Mathangi in Chandalabhikshuki. These two poems stand apart in Asan's oeuvre since they explicitly portray the contemporary Kerala life. "The upper world" and "lower world" in Duravastha stands for the uppercaste- lowercaste dichotomy in Kerala. Chathan who belongs to the lower world is redeemed and uplifted to the upper world through the medium of Savithri, the Namboodiri Antharjanam. In her mission she tries to educate the lowercaste masses, which alone she thinks can ameliorate the respect they receive. But here Savitri also, like many social reformers in Kerala, emphasized not on an annihilation of caste but, realized that it was the religious reform that was instrumental in introducing caste reform. Savitri insists on reformations with the Pulaya customs, beginning with mass education and upliftment. In Kumaranasan's other works like Nalini, Karuna and Chandaabhikshuki, it was always Divakaran, Upaguptan and Buddhan who adorned the position of the Guru. But in Duravastha, it was a woman, though belonged to an upper caste like othermen, who gained the position. The actions of Savitri reinforce the teaching of SreeNarayana Guru who put forth the panacea to dissolve the caste dichotomy as education. But to a great extent Duravastha reestablishes the hegemonic caste relationship while presenting education and power as the symbols for supremacy and nativity and indigenousness of lower castes as denigrated. In Savitri's vision, Chathan is superficially defiled from which he is to be purified using the Savarna tools. Though the poem stands against the caste based oppression, nowhere can we find the dreams and visions of Chathan, the lowercaste hero. The social reformation through the perspective of a Savarna lady only finds space. Thus he is silenced.

Though Asan lashes out against caste hierarchy directly in Duravastha, in Chandalabhikshuki, he makes Buddha his prolocutor. Unlike other women characters of Kumaranasan, Mathangi is virtually silenced in the poem except for one instance when the Buddhist monk asks for water. This reveals a silent submission of the lower castes before the upper caste, undenying any intervention from the 
upper castes even into their private lives. Both these poems portray the defilement of lower caste civilization which can be sanctified only with the involvement of upper caste initiative. Here the impurity of Mathangi is not the outcome of any of her deeds as for Vasavadatha in Karuna, but the consequence of her birth in a lower caste. Thus even Asan's poems which contributed a great deal to the social reform in Kerala compromises at times with the existing hierarchical norms.

But towards the end of colonial rule in Kerala, there came a sea change in the casteism in Kerala society. During the social practices based on purity and pollution which supposedly underpinned the hierarchical caste, they had either become virtually nonexistent or totally obsolete. For instance, during mid-twentieth century, teashops and other public conveniences began to sprout up even in rural areas which happily stared catering to men from all castes. The emergence of nationalist, anti-caste and radical movements had contributed profusely to the birth of a progressive civil society in late colonial Kerala.

The decline of feudalism which paved for the emergence of industrial capitalism altered the traditional balance of power in colonial Kerala. The caste system gradually gave way to a virtual class system, though within its casteist purview. The emerging middle class mediated radical social reforms and thereby released the society from regressive socialites. The progressive social reformers from this class entered the political area later. Most of the caste and religious divisions were severely undermined by class movements, which led to the absence of any dominant caste in the entire Kerala society.

The Communist movement which flourished in Kerala also contributed to this sidelining of casteism and the upheaval of the idea of class struggle. But the irony is that most people who belonged to the upper class were those who were called "upper castes" earlier. However the absence of a single dominant caste anticipated prolonged conflict, mediation and bargaining between caste and classes facilitated progressive secularization and democratization of Kerala society which was indeed brought about by the radical reform movements.

Thakazhi Sivasankara Pillai's Thottiyude Makan and Randidangazhi reflects this transience in conception from caste to class. A wave of transformation in the zeitgeist of humanity is apparent in these novels. It clearly demonstrates the destructuring and restructuring of Kerala society. It doesnot mean simply to expose the oppression faced by the lower castes turned lowerclass of the society but to establish the emergence of class consciousness. They aimed at developing confidence and selfconsciousness among the oppressed or the lower class people to redeem themselves from the shackles of the privileged. Communist movements and the growth of proletarianism in Kerala, presented in these novels, truly substantiates the evolution of casteist to a more class specific one. The people were made aware of their caste deprivations, enabling them to voice out their own rights. The proletariat struggles presented in these novels implicitly speaks of the amelioration of the so called "lower castes" which became instrumental in determining the later stage casteism developed in Kerala society.

P.Kesavadev through his Ayalkar gives us a vivid description of the decline of matrilineal feudalist system within the Nair community simultaneously addressing the up gradation of Ezhava community which was till then considered an untouchable caste. Evidenty the progress of Ezhava community was heavily influenced by the radical reform and Communist movements in Kerala. In Ayalkar,Kesavadev portrays the thinning of demarcation between the social status of Nair and Ezhava community. The degeneration of a Nair "tharavad" and the sustenance of its members with the aid of an Ezhava family headed by the former caretaker of the "tharavad", Kunjan substantiate this view. Though it was indigestible in one morsel, the upper castes in Kerala gradually began to overcome the segregation and discrimination earlier practiced towards the lower strata. Moreover through these novels an inclination of Kerala society towards leftist ideology became evident. This further contributed to the dormancy of casteist mindset in Kerala society. Many inter-caste marriages and inter-dining missions were undertaken under the purview of socio-political reformation. An intelligentsia emerged which considered the pubic proclamation of caste as shame and humiliation. But this attitude did not percolate into the laymen's lives or priorities. Though the class structure of post-colonial Kerala 
society contained within itself deeper and subtler possibilities of anti-secular articulations of caste, it also presumes the scope for a more egalitarian and radical society.

But the casteless society remained a distant dream since the people of Kerala were interested in attaining solidarity with the people of their own caste. Many caste associations formed in Kerala, though were nonpolitical initially, gradually intervened in politics. A slackening of political modernization in Kerala occurred from the time of Abstention movement, as a result of the involvement of caste associations in politics. With the evolution of caste association as a way of public life in Kerala, the casteist activities grew up which seriously affected the once heralded democratic political development.

Moving towards the last three decades of 20th century, in the opinion of P.K. Balakrishnan, a new casteist structure surfaced in Kerala which promised a distinct space for Nairs, "foreign" Brahmins like Tamil Brahmins and a voice for the elevated Ezhava community. Contrastingly during this period, the Namboodiri community got sidelined in the economic as well as the political scenario. It is here, the relevance of Thalamurakal by O.V. Vijayan occurs. Through this novel, Vijayan overviews the conception of caste that prevailed in the minds of Kerala people for many years. He views the identity and the selfhood of Kerala as inextricably intertwined with the casteism of the society. He portrays the evolution of an Ezhava family which tries to overcome its existential crisis in an educated, but casteist milieu. Through the demolition of Ponmudi tharavad, Vijayan delineates the condition of Kerala society of the 18th and 19th century. He sharply shoots at an younger generation of people who scorns at their own casteist traditions especially occupations. The constant striving of the "lower castes" to attain Brahmanism to overcome their inferiority complex is severely condemned. Each generation in Thalamurakal disdains their own tradition and attempts to gain domination in society through money and aristocracy. From Krishnan, who went to Kasi borrowing the cross thread of Namboodiri, to Chamiyaarappan who revolted before the "agraharam" of Kalpaathi, there is a constant striving from each generation to attain Brahmanism and thereby overcome the internalized inferiority feeling. Consistent assertion is made by each generation throughout the novel to equalize them with the Brahmins or the upper castes. This novel by Vijayan is indeed a subversion of the egalitarian ideologies propagated by the Kerala Renaissance. He lashed out at the ostensible promises of social reform movements in Kerala which in no way destabilized the casteist networks.

Indisputably in the twenty first century, a typical Malayali household is unable toovercome the casteist fever that creeped into its mind centuries ago. Though inter-caste marriages augment in Kerala, it is still an unconceivable notion for a middle class family, especially among the "upper castes". Truly no one dares to speak out "caste" in today's Kerala but the hard fact that caste is deeply ingrained in the mental fabric of Keralites cannot be left unnoticed. Manushyanu Oru Aamukham, the Sahitya Akademi Award winning novel by Subhash Chandran, fundamentally presumes every educated Keralite who swears against casteism, as being unknowingly bound by it.

In other words, this "silenced caste" could not head to any annihilation of casteism but only to a silent consolidation of casteism in the mental horizon of the public. As Subhash Chandran puts forth in his Manushyanu Oru Aamukham, caste forms the only panacea to an "upper caste" Malayali when he fails to achieve any remarkable feat.

\section{REFERENCES}

[1] Balakrishnan, P.K. Jativyavasthayum Keralacharithravum. Kottayam: NBS, 1983. Print

[2] Chandran, Subhash. Manushyanu Oru Aamukham. Kottayam: DC Books, 2010. Print.

[3] Chendarasseri, T.H.P. Keralacharithrathinu Oru Mukhavura. Thiruvananthapuram: Mythri Books, 2015. Print.

[4] Cherian, P. J. Perspectives on Kerala History: The Second Millennium. Vol. II Part. II. Kerala:Kerala Gazetters, 1999. Print.

[5] Gopakumar, Dr. P.F. Faces of Social Reform in Kerala. Thiruvananthapuram: Akshara, 2015. Print.

[6] Gurukkal, Rajan and M.R.Raghava Varier. Cultural History of Kerala. Vol. I. Kerala: Dept. of Cultural Publications, 1999. Print. 
From Social Polarity to Mental Polarity: Tracing the Paradigmatic Shifts in the Conception of "Caste" in Kerala

[7] Nair,Prof. Panmana Ramachandran. Novel Padanangal. Thiruvananthapuram: Current Books, 2004. Print.

[8] Namboodiripad, E.M.S. Kerala Charithram: Marxist Veekshanathil. Thiruvananthapuram: Chintha Publishers, 1990. Print.

[9] Panikkar, Dr. K. Ayyappa. Thakazhi Sivasankara Pillai. Kottayam: DC Books, 1992. Print.

[10] Panikkar, G.N. Dev...Kesavdev. Thiruvananthapuram: Prabhat Book House, 1993. Print.

[11] Reddy, Justice O. Chinnappa. Religion, Caste and the Threat to Secularism. Thiruvananthapuram: Dept.of Pubications, 2006. Print.

[12] Vijayan, O.V. Thalamurakal. Kottayam: DC Books, 1997. Print.

\section{AUTHOR's BIOGRAPHY}

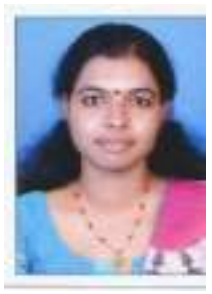

Jyothi Lekshmi G, working as Guest Lecturer in the Department of English, NSS College, Nilamel, Kollam, Kerala, India. Her academic interests mainly thrusts on Culture Studies, Translation Studies, Kerala Studies and Comparative Literature.

Citation: Jyothi lekshmi G. " From Social Polarity to Mental Polarity: Tracing the Paradigmatic Shifts in the Conception of "Caste" in Kerala." International Journal of History and Cultural Studies (IJHCS), vol 3, no. 4, 2017, pp. 45-50. doi:DOI: http://dx.doi.org/ 10.20431/2454-7654.0304005.

Copyright: () 2017 Authors. This is an open-access article distributed under the terms of the Creative Commons Attribution License, which permits unrestricted use, distribution, and reproduction in any medium, provided the original author and source are credited. 